\title{
Sodium Fluoride Arrests Renal G2/M Phase Cell-Cycle Progression by Activating ATM- Chk2-P53/Cdc25C Signaling Pathway in Mice
}

\author{
Qin Luo Hongrui Guo ${ }^{a}$ Ping Kuang ${ }^{a}$ Hengmin Cui ${ }^{a}, b, c$ Huidan Deng ${ }^{a}$ Huan Liu ${ }^{a}$ \\ Yujiao Lu Qin Wei $^{a}$ Linlin Chen ${ }^{a}$ Jing Fang ${ }^{a, b}$ Zhicai Zuo ${ }^{a, b}$ Junliang Denga,b \\ Yinglun Li $i^{a, b} \quad$ Xun Wang ${ }^{a, b} \quad$ Ling Zhao ${ }^{a, b}$ \\ aCollege of Veterinary Medicine, Sichuan Agricultural University, Ya'an, 'Key Laboratory of Animal \\ Diseases and Environmental Hazards of Sichuan Province, Sichuan Agriculture University, Chengdu, 'Key \\ Laboratory of Agricultural information engineering of Sichuan Province, Sichuan Agriculture University, \\ Ya'an, China
}

\section{Key Words}

Sodium fluoride $\cdot$ G2/M phase arrest $\cdot$ ATM-Chk2-p53/Cdc25C signaling pathway $•$ Proliferation - Kidney $\bullet$ Mice

\begin{abstract}
Background/Aims: Excessive fluoride intake can induce cytotoxicity, DNA damage and cellcycle changes in many tissues and organs, including the kidney. However, the underlying molecular mechanisms of fluoride-induced renal cell-cycle changes are not well understood at present. In this study, we used a mouse model to investigate how sodium fluoride (NaF) induces cell-cycle changes in renal cells. Methods: Two hundred forty ICR mice were randomly assigned to four equal groups for intragastric administration of $\mathrm{NaF}(0,12,24$ and $48 \mathrm{mg} / \mathrm{kg}$ body weight/day) for 42 days. Kidneys were taken to measure changes of the cell-cycle at 21 and 42 days of the experiment, using flow cytometry, quantitative real-time polymerase chain reaction (qRT-PCR) and western blot methods. Results: NaF, at more than $12 \mathrm{mg} / \mathrm{kg}$ body weight, induced G2/M phase cell-cycle arrest in the renal cells, which was supported by the finding of significantly increased percentages of renal cells in the G2/M phase. We found also that G2/M phase cell-cycle arrest was accompanied by up-regulation of $p-A T M, p-C h k 2$, p-p53, p-Cdc25C, p-CDK1, p21, and Gadd45a protein expression levels; up-regulation of ATM, Chk2, p53, p21, and Gadd45a mRNA expression levels; down-regulation of CyclinB1, mdm2, PCNA protein expression levels; and down-regulation of CyclinB1, CDK1, Cdc25C, mdm2, and PCNA mRNA expression levels. Conclusion: In this mouse model, NaF, at more than $12 \mathrm{mg} /$ $\mathrm{kg}$, induced G2/M phase cell-cycle arrest by activating the ATM-Chk2-p53/Cdc25C signaling

Q. Luo, H. Guo and P. Kuang contributed equally to this work.

$\begin{array}{ll}\text { Hengmin Cui } & \text { College of Veterinary Medicine, Sichuan Agricultural University } \\ & \text { 46 Xinkang Rd, Yaan, Sichuan, } 625014 \text { (China) } \\ & \text { Tel. }+8613608264628, \text { Fax }+8608352882340 \text {, E-Mail cui580420@sicau.edu.cn }\end{array}$
\end{abstract}


pathway, which inhibits the proliferation of renal cells and development of the kidney. Activation of the ATM-Chk2-p53/Cdc25C signaling pathway is the mechanism of NaF-induced renal G2/M phase cell-cycle arrest in this model.

\section{Introduction}

Fluoride is a ubiquitous ingredient of drinking water, foodstuffs, medicines and dental products $[1,2]$, and it is widely used in a variety of industrial practices, such as the production of phosphoric acid, phosphate fertilizers, ceramics, aluminum, steel, and brick [3]. Moreover, $\mathrm{NaF}$ is a useful phosphatase inhibitor. According to World Health Organization guidelines, the recommended concentration of fluoride in drinking water is $1.0 \mathrm{mg} / \mathrm{L}$, and the upper limit is $1.5 \mathrm{mg} / \mathrm{L}$ [4]. Especially high fluoride concentrations in nature have been found in India, Mexico, Turkey, North Africa and China (Yunnan, Gui zhou) [5]. Excessive fluoride intake can cause dental and skeletal fluorosis in animals and humans [6, 7] as well as structural and functional changes in soft tissues, including brain [8-10], thymus [11,12], liver [13-15], heart [11, 16], lung [17], spleen [18-21], intestine [22, 23], cecal tonsil [24, 25], reproductive organs [26] and the bursa of Fabricius [27]. As the major organ involved in retention and excretion of fluoride, the kidney is sensitive to fluoride toxicity [28]. And previous studies have demonstrated that high doses of fluoride can induce cytotoxicity, lipid peroxidation, DNA damage, apoptosis and cell-cycle changes in the kidney [29, 30].

The cell-cycle is a complex process that participates in the growth and proliferation of cells, development of organisms, regulation of DNA damage repair, and diseases such as cancer [31]. The divisions of the standard cell-cycle are G1 (cell prepares for DNA synthesis), $S$ (cell is synthesizing DNA), G2 (cell prepares for mitosis), and mitosis (M) phases [32]. Cells in the G1 phase can enter a resting state called the G0 phase, which usually indicates potential for cell division. Cell transition from one cell-cycle phase to another occurs in an orderly fashion and is regulated by cell-cycle-regulating proteins, such as the cyclin proteins and cyclin-dependent kinases (CDKs) [33]. Checkpoints also exist in the cell-cycle to ensure correct cell-cycle progression. Cell-cycle checkpoints are mainly positioned before the cell enters $\mathrm{S}$ phase (G1/S checkpoint), after DNA replication (G2/M checkpoint) or during $\mathrm{S}$ phase (S checkpoint) [34]. In response to DNA damage, cell-cycle checkpoints arrest the cell-cycle progression to provide more time for DNA repair [35]. The prolonged cell-cycle arrest disrupts the balance between cell proliferation and cell death, and ultimately results in cellular growth arrest or death [36]. Bai et al. [37] have reported that excessive sodium fluoride (NaF) intake can induce G0/G1 phase cell-cycle arrest of renal cells in chickens. Also, NaF, at the dose of $50 \mathrm{mg} / \mathrm{L}$, reduced the number of rat renal cells in G2/M phase [38], and excessive $\mathrm{NaF}$ induced loss of control in proliferation of rat renal cells by disturbing the G1/S and G2/M phase [39]. However, there are inconsistencies in these reports about the effects of fluoride on the renal cell-cycle.

The cell-cycle is controlled by numerous mechanisms that ensure correct cell division. Ataxia-telangiectasia-mutated (ATM), as a sensor of DNA damage, plays an important role in cell proliferation and DNA repair [40]. Recent studies have reported that ATM-dependent signaling pathways participate in the regulation of multiple cell-cycle checkpoints, and the activation of ATM-dependent signaling pathways can induce the expression of many genes that are involved in cellular functions, such as cell-cycle arrest, DNA repair, or apoptosis [40]. However, there are no studies on the molecular mechanisms of fluoride-induced renal cellcycle changes in animals and humans.

In this study, we first used a mouse model to investigate, by flow cytometry, the effects of fluoride on the cell-cycle in renal cells. We then explored the underlying molecular mechanisms of NaF-induced renal cell-cycle changes by measuring protein expression levels of phosphor-ATM (p-ATM, Ser-1981), p-checkpoint kinase 2 (p-Chk2, Thr-68), p-p53 (Ser15), p21, growth arrest and DNA-damage-inducible protein 45 alpha (Gadd45a), Cyclin $B_{1}$, p-CDK1 (Tyr-15), p-cell division cyclin 25C (p-Cdc25C, Ser-216), murine double minute 2 


\section{Cellular Physiology Cell Physiol Biochem 2018;51:2421-2433 and Biochemistry Published onlıne: 8December $2018 \begin{aligned} & \text { DO } 2018 \text { The Author(s). Published by S. Karger AG, Basel } \\ & \text { www.karger.com/cpb }\end{aligned}$ Luo et al:: Sodium Fluoride Arrests Renal G2/M Phase Cell-Cycle Progression in the Mouse}

(mdm2) and proliferating cell nuclear antigen (PCNA) with western blot; and by measuring mRNA expression levels of ATM, Chk2, p53, p21, Gadd45a, Cyclin B, CDK1, Cdc25C, mdm2 and PCNA with quantitative real-time polymerase chain reaction (qRT-PCR).

\section{Materials and Methods}

\section{Chemicals and sources}

$\mathrm{NaF}$ was obtained from Chengdu Kelong Chemical Co., Ltd. (Chengdu, China). RNAiso Plus, Prim-Script ${ }^{\mathrm{TM}}$ RT reagent Kit and SYBR $®$ Premix Ex Taq ${ }^{\mathrm{TM}}$ II were supplied by Takara Biotechnology (Dalian) Co., Ltd. (Dalian, Liaoning, China). Radio-immunoprecipitation Assay (RIPA) lysis buffer (P0013C), phenylmethylsulfonyl fluoride (PMSF, ST506), and Bicinchoninic acid Protein Assay Kit (P0012) were obtained from Beyotime Biotechnology, China. Mouse p-ATM (651201) was supplied by Biolegend Inc. (Biolegend, CA, USA). P-Cdc25C (orb304716) was purchased from Biorbyt, UK. Cyclin B ${ }_{1}$ (4138), p-p53 (9284), p-CDK1 (9111), PCNA (13110), $\beta$-actin (4970), anti-rabbit IgG (7074) and anti-mouse IgG (7076) were obtained from Cell Signaling Technology, USA. P-Chk2 (bs-3721R) was purchased from Bioss Biotechnology, Inc. (Bioss, Beijing, China). Mdm2 (ab178938) was purchased from Abcam, UK. P21 (BA0272) was supplied by Boster Biological Technology Co., Ltd (Boster, Wuhan, China). Gadd45a was obtained from Absin Bioscience Inc. (Absin, Shanghai, China). Other chemicals, including 75\% ethanol, 100\% ethanol, isopropyl alcohol and chloroform, were of analytical grade.

\section{Experimental animals and treatment}

One hundred twenty male and one hundred twenty female four-week-old ICR mice were obtained from Chengdu Dossy Experimental Animals Co., Ltd [License No. SCXK (Sichuan) 2008-24]. and housed in separate cages. All animals were allowed access to diet and water ad libitum throughout the experimental period. After one week of acclimatization, animals were randomized into four groups of 60 animals each for 42 days. Control group (untreated) animals were given distilled water by gastric gavage $(1 \mathrm{ml} / 100 \mathrm{~g}$ body weight). Groups I, II and III were given $\mathrm{NaF}$ by gastric gavage ( $1 \mathrm{ml} / 100 \mathrm{~g}$ body weight) at the dose of 12,24 and $48 \mathrm{mg} / \mathrm{kg}$ body weight, respectively.

All experimental procedures involving the use of mice were approved by the Animal Care and Use Committee of Sichuan Agricultural University.

\section{Determination of viscera index of the kidney}

At 21 and 42 days of the experiment, the body weight and kidney weight of four male and four female mice in each group were recorded. Viscera index of the kidney was calculated by the formula: Viscera index $=$ kidney weight $(\mathrm{g}) /$ body weight $(\mathrm{kg})$.

Determination of cell-cycle phase changes in the kidney by flow cytometry

At 21 and 42 days of the experiment, kidneys of four male and four female mice from each group were taken to measure the renal cell-cycle by flow cytometry. Kidneys were crushed, filtered with $300-$ mesh nylon membrane, centrifuged $(600 \times \mathrm{g}, 5 \mathrm{~min})$, and adjusted to a cell density of $1.0 \times 10^{6} \mathrm{cells} / \mathrm{mL}$ with phosphate-buffered saline (PBS, pH 7.2-7.4). Then $500 \mu \mathrm{L}$ cell suspensions were transferred to culture tubes and centrifuged $(600 \times \mathrm{g}, 5 \mathrm{~min})$ once more. The supernatant was decanted, and cells were incubated at room temperature in the dark $(30 \mathrm{~min})$ with $0.25 \%$ Triton X-100 and propidium iodide (51-66211E, BD, USA). Finally, $500 \mu \mathrm{L}$ of PBS were added to each tube, and stained cells were analyzed with BD FACS Calibur flow cytometer within $45 \mathrm{~min}$. The results were analyzed by use of the Mod Fit LT for Mac V3.0 computer program.

Determination of cell-cycle regulatory molecule mRNA expression levels in the kidney by qRT-PCR

At 21 and 42 days of the experiment, four male and four female mice form each group were sacrificed, and the kidneys were removed immediately. The kidneys were homogenized in liquid nitrogen for RNA extraction. Total RNA was extracted with RNAiso Plus (9109; Takara, China), according to the manufacturer's protocols. The CDNA was synthesized with a Prim-Script ${ }^{\mathrm{TM}} \mathrm{RT}$ reagent Kit (RR047A, Takara, China) according to the manufacturer's instructions. Information of genes was acquired from the National Center for 


\section{Cellular Physiology Cell Physiol Biochem 2018;51:2421-2433

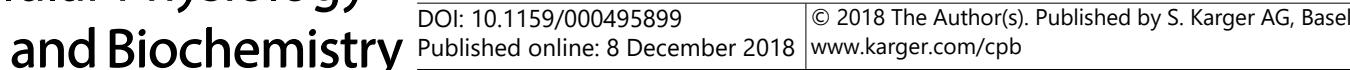 \\ Luo et al.: Sodium Fluoride Arrests Renal G2/M Phase Cell-Cycle Progression in the Mouse}

Biotechnology Information, and primers were designed and synthesized by Sangon (Shanghai, China). $\beta$-actin, a house-keeping gene, was used as an internal control. The accession number, sequence, product size and $\operatorname{Tm}\left({ }^{\circ} \mathrm{C}\right)$ of the primers are listed in Table 1. The mRNA expression levels of ATM, Chk2, p53, p21, Gadd45a, Cyclin $\mathrm{B}_{1}$, CDK1, Cdc25C, mdm2 and PCNA were determined with SYBR@ Premix Ex Taq ${ }^{\mathrm{TM}}$ II (RR820A, Takara, China) according to the manufacturer's instructions. The results of qRT-PCR were analyzed with the $2^{-\Delta \Delta C T}$ method [41].

Determination of cell-cycle regulatory molecule protein expression levels in the kidney with western blot The kidneys used for measuring the mRNA expression levels of ATM, Chk2, p53, p21, Gadd45a, Cyclin $\mathrm{B}_{1}$, CDK1, Cdc25C, mdm2 and PCNA were used also for measuring the protein expression levels of p-ATM, p-Chk2, p-p53, p21, Gadd45a, Cyclin B , p-CDK1, p-Cdc25C, mdm2 and PCNA. The kidneys were homogenized in liquid nitrogen with RIPA lysis buffer supplemented with $1 \mathrm{mM}$ PMSF. Protein content of the kidneys was measured with the Bicinchoninic acid Protein Assay Kit. The protein samples were separated by sodium dodecyl sulfate-polyacrylamide gel electrophoresis (SDS-PAGE; 5\%-15\% gels), with protein standards used as molecular weight markers. After electrophoresis, proteins were transferred to nitrocellulose filter membranes. The membranes were blocked with 5\% nonfat-dried milk in phosphate-buffered saline with $0.1 \%$ Tween 20 for $1 \mathrm{~h}$ and incubated with primary antibodies overnight at $4^{\circ} \mathrm{C}$. The primary antibodies were p-ATM (dilution, 1:500; $350 \mathrm{kDa}$ ), p-Chk2 (dilution, 1:100; $62 \mathrm{kDa}$ ), p-p53 (dilution, 1:1500; 53 kDa), p21 (dilution, 1:200; $21 \mathrm{kDa}$ ), Gadd45a (dilution, 1:800; $18 \mathrm{kDa}$ ), Cyclin $\mathrm{B}_{1}$ (dilution, 1:1000; 55 $\mathrm{kDa}$ ), p-CDK1 (dilution, 1:800; $34 \mathrm{kDa}$ ), p-Cdc25C (dilution, 1:500; $53 \mathrm{kDa}$ ), mdm2 (dilution, 1:500; 90 $\mathrm{kDa}$ ) and PCNA (dilution, 1:1000; $29 \mathrm{kDa}$ ). After the primary antibodies had been incubated overnight, the membranes were washed three times in phosphate-buffered saline with $0.1 \%$ Tween 20 for 10 min, incubated with biotin-conjugated secondary antibodies for $1 \mathrm{~h}$ with gentle shaking, and washed again in phosphate-buffered saline with $0.1 \%$ Tween 20. Blots were visualized with ECL ${ }^{\text {TM }}$ (Bio-Rad, Hercules, CA, USA) and X-ray film. Protein expression was measured with ImageJ2x software.

\section{Statistical Analysis}

The SPSS 17.0 statistical software package programme for windows was used for variance tests. All results were presented as mean \pm standard deviation. The significance of difference between the control group and the three experimental groups was analyzed with one-way analysis of variance. Differences were considered statistically significant at $p<0.05$.

\section{Results}

\section{Changes of viscera index and volumes of the kidney}

Fig. 1a-b shows that the renal volumes were smaller in the 12,24 and $48 \mathrm{mg} / \mathrm{kg}$ groups at 21 and 42 days of the experiment than those in the control group. As seen in Fig. 1c, the renal viscera index was lower $(p<0.01$ or $p<0.05)$ in the 24 and $48 \mathrm{mg} / \mathrm{kg}$ groups at 21 and 42 days than those in the control group. 
Fig. 1. Changes of renal volumes and viscera index at 21 and 42 days of the experiment. a The kidneys at 21 day of the experiment (from left to right are the control group, $12 \mathrm{mg} / \mathrm{kg}, 24$ $\mathrm{mg} / \mathrm{kg}$ and $48 \mathrm{mg} / \mathrm{kg}$ groups). b The kidneys at 42 day of the experiment (from left to right are the

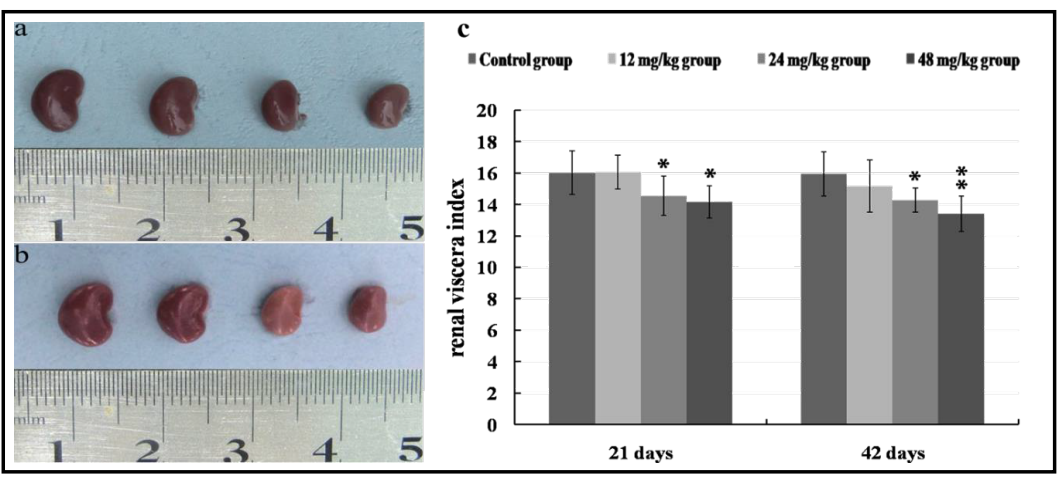
control group, $12 \mathrm{mg} / \mathrm{kg}, 24 \mathrm{mg} / \mathrm{kg}$ and $48 \mathrm{mg} / \mathrm{kg}$ groups). c Renal viscera index at 21 and 42 days of the experiment. Data are presented with the means \pm standard deviation $(n=8) .{ }^{*} p<0.05$, compared with the control group; ${ }^{* *} \mathrm{p}<0.01$, compared with the control group.

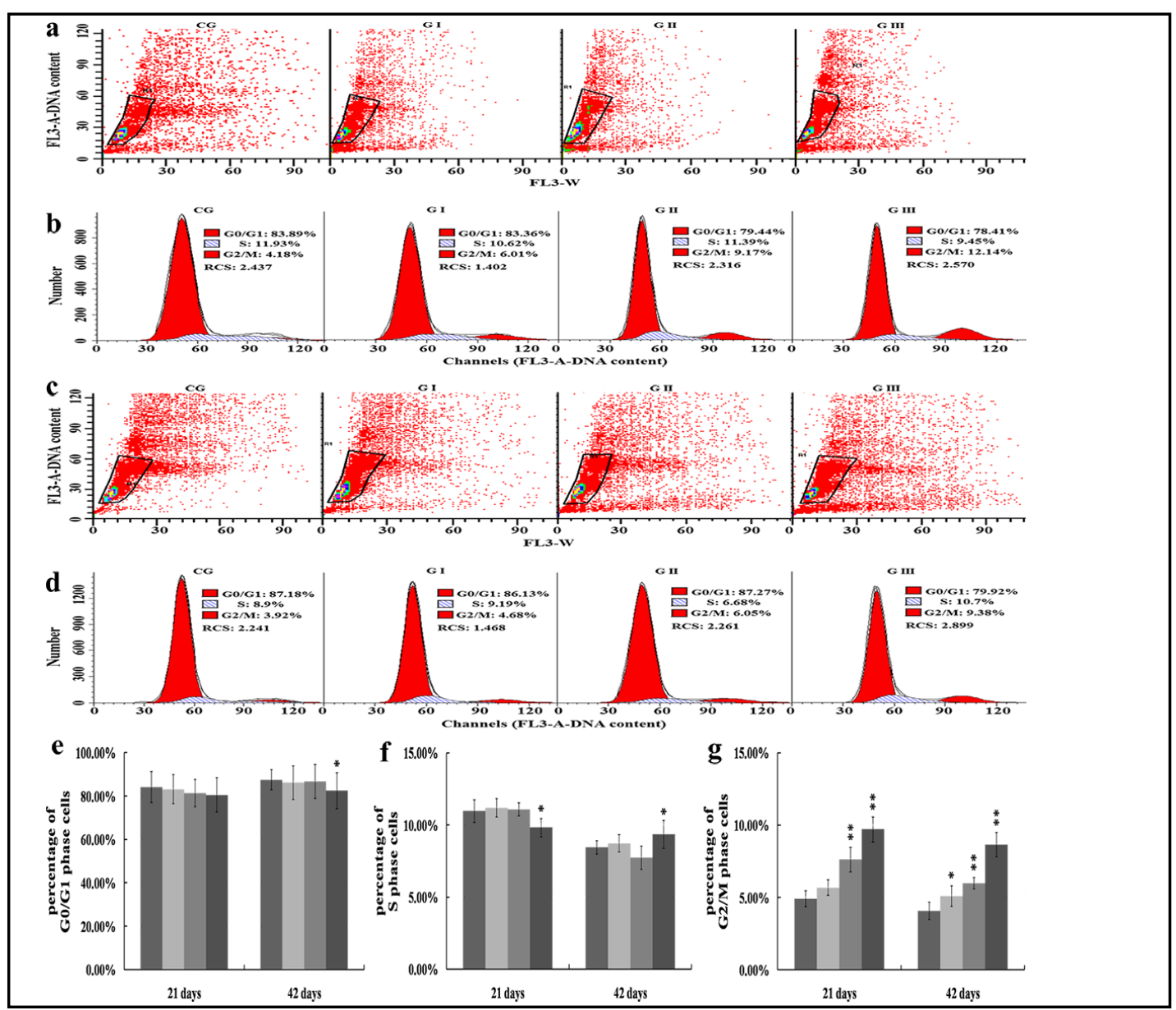

Fig. 2. Changes of renal cell-cycle phase distribution in the kidney at 21 and 42 days of the experiment. a-b The diagram of renal cell-cycle phase distribution obtained by flow cytometry at 21 days of the experiment. c-b The diagram of renal cell-cycle phase distribution obtained by flow cytometry at 42 days of the experiment. e The percentages of G0/G1 phase cells. $f$ The percentages of S phase cells. $g$ The percentages of G2/M phase cells. CG: Control group; GI: $12 \mathrm{mg} / \mathrm{kg}$ group; GII: $24 \mathrm{mg} / \mathrm{kg}$ group; GIII: $48 \mathrm{mg} / \mathrm{kg}$ group. Data are presented with the means \pm standard deviation $(n=8) .{ }^{*} p<0.05$, compared with the control group; ${ }^{* *} p$ $<0.01$, compared with the control group. 


\section{Changes of cell-cycle phase in the kidney}

The percentages of G2/M phase cells were increased $(p<0.05)$ in the $12 \mathrm{mg} / \mathrm{kg}$ group at 42 days of the experiment and were significantly increased $(p<0.01)$ in the 24 and 48 $\mathrm{mg} / \mathrm{kg}$ groups at 21 and 42 days of the experiment in comparison with percentages in the control group. The percentages of G0/G1 phase cells were lower $(p<0.05)$ in the $48 \mathrm{mg} / \mathrm{kg}$ group at 42 days of the experiment than in the control group. The percentages of $\mathrm{S}$ phase cells were decreased $(p<0.05)$ in the $48 \mathrm{mg} / \mathrm{kg}$ group at 21 days and increased $(p<0.05)$ in the $48 \mathrm{mg} / \mathrm{kg}$ group at 42 days compared with percentages in the control group. The results are shown in Fig. 2.

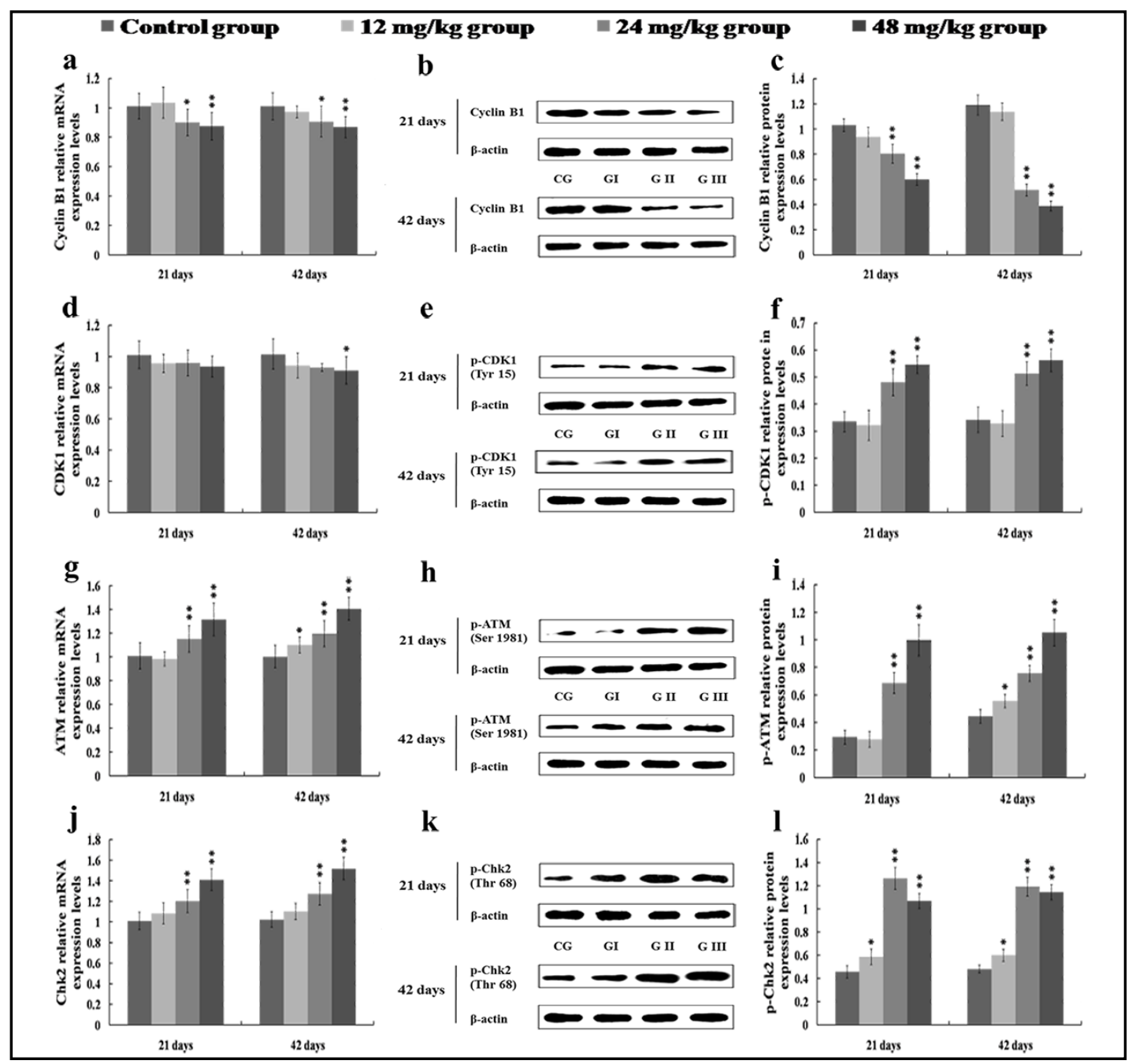

Fig. 3. Changes of mRNA and protein expression levels of Cyclin B1, CDK1, ATM, Chk2 in the kidney at 21 and 42 days of the experiment. a The relative mRNA expression levels of Cyclin B1. b The western blot assay of Cyclin B1. c The relative protein expression levels of Cyclin B1. $d$ The relative mRNA expression levels of CDK1. e The western blot assay of $\mathrm{p}$-CDK1. $\mathrm{f}$ The relative protein expression levels of $\mathrm{p}$-CDK1. $\mathrm{g}$ The relative mRNA expression levels of ATM. $h$ The western blot assay of p-ATM. $i$ The relative protein expression levels of p-ATM. j The relative mRNA expression levels of Chk2. $\mathrm{k}$ The western blot assay of $\mathrm{p}$-Chk2. 1 The relative protein expression levels of p-Chk2. CG: Control group; GI: $12 \mathrm{mg} / \mathrm{kg}$ group; GII: $24 \mathrm{mg} / \mathrm{kg}$ group; GIII: 48 $\mathrm{mg} / \mathrm{kg}$ group. Data are presented with the mean \pm standard deviation $(\mathrm{n}=8),{ }^{*} \mathrm{p}<0.05$, compared with the control group; ${ }^{* *} \mathrm{p}<0.01$, compared with the control group. 
Changes of cell-cycle regulatory molecule $m R N A$ and protein expression levels in the kidney

The Cyclin B1 mRNA and protein expression levels were lower $(p<0.01$ or $p<0.05)$ in the 24 and $48 \mathrm{mg} / \mathrm{kg}$ groups at 21 and 42 days of the experiment than in the control group, as shown in Fig. 3a-c. Fig. 3d shows that the CDK1 mRNA expression levels were decreased $(p<0.05)$ in the $48 \mathrm{mg} / \mathrm{kg}$ groups at 42 days of the experiment in comparison with those in the control group. The results in Fig. 3e-f shows that the p-CDK1 protein expression levels were higher $(p<0.01)$ in the 24 and $48 \mathrm{mg} / \mathrm{kg}$ groups at 21 and 42 days of the experiment than those in the control group.

Fig. 3g-i shows that the ATM mRNA and p-ATM protein expression levels were significantly increased $(p<0.01$ or $p<0.05$ ) in the $12 \mathrm{mg} / \mathrm{kg}$ group at 21 and 42 days of the experiment and in the 24 and $48 \mathrm{mg} / \mathrm{kg}$ groups at 21 and 42 days of the experiment compared with those in the control group.

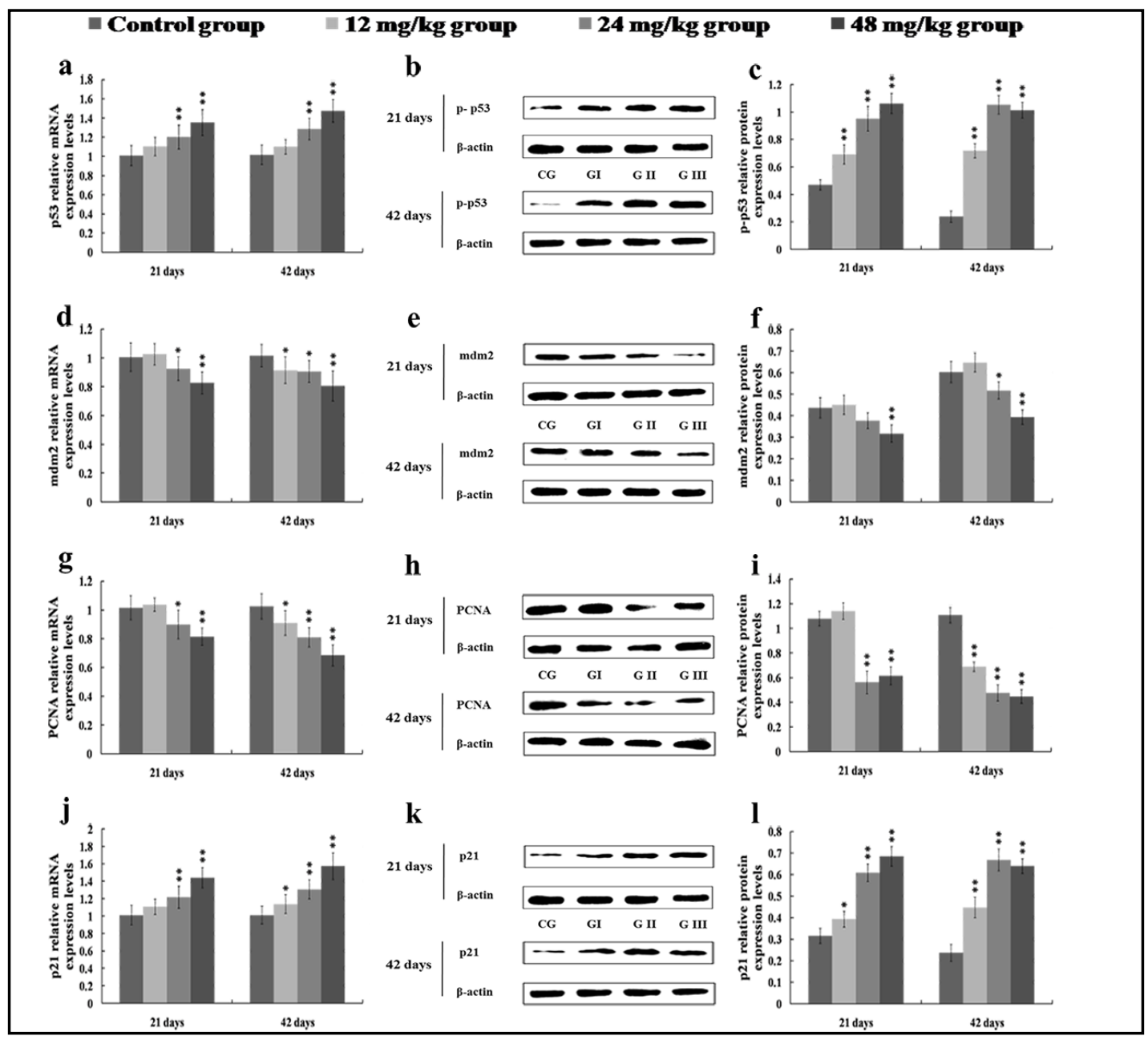

Fig. 4. Changes of mRNA and protein expression levels of $p 53, \mathrm{mdm} 2$, PCNA, p21 in the kidney at 21 and 42 days of the experiment. a The relative mRNA expression levels of p53. b The western blot assay of p-p53. c The relative protein expression levels of p-p53. $d$ The relative mRNA expression levels of mdm2. e The western blot assay of mdm2. $f$ The relative protein expression levels of mdm2. $g$ The relative mRNA expression levels of PCNA. $h$ The western blot assay of PCNA. i The relative protein expression levels of PCNA. $\mathrm{j}$ The relative mRNA expression levels of $\mathrm{p} 21 . \mathrm{k}$ The western blot assay of $\mathrm{p} 21 . \mathrm{l}$ The relative protein expression levels of p21. CG: Control group; GI: $12 \mathrm{mg} / \mathrm{kg}$ group; GII: $24 \mathrm{mg} / \mathrm{kg}$ group; GIII: $48 \mathrm{mg} / \mathrm{kg}$ group. Data are presented with the mean \pm standard deviation $(n=8),{ }^{*} p<0.05$, compared with the control group; ${ }^{* *} \mathrm{p}<0.01$, compared with the control group. 
The Chk2 mRNA and p-Chk2 protein expression levels were significantly increased ( $p$ $<0.01$ ) in the 24 and $48 \mathrm{mg} / \mathrm{kg}$ groups at 21 and 42 days of the experiment compared with those in the control group. The p-Chk2 protein expression levels were significantly increased $(p<0.05)$ in the $12 \mathrm{mg} / \mathrm{kg}$ groups at 42 days of the experiment compared with those in the control group. The results are shown in Fig. 3j-l.

Fig. 4a shows that p53 mRNA expression levels were significantly increased $(p<0.01)$ in the 24 and $48 \mathrm{mg} / \mathrm{kg}$ groups at 21 and 42 days of the experiment compared with those in the control group. The p-p53 protein expression levels were significantly increased $(p<0.01)$ in the 12,24 and $48 \mathrm{mg} / \mathrm{kg}$ groups at 21 and 42 days of the experiment compared with those in the control group, as shown in Fig. 4b-c.

The mdm 2 mRNA expression levels were decreased $(p<0.01$ or $p<0.05)$ in the $12 \mathrm{mg} /$ $\mathrm{kg}$ groups at 42 days of the experiment and in the 24 and $48 \mathrm{mg} / \mathrm{kg}$ groups at 21 and 42 days compared with those in the control group, as shown in Fig. 4d. Fig. 4e-f shows that the $\mathrm{mdm} 2$ protein expression levels were reduced $(p<0.01$ or $p<0.05)$ in the $24 \mathrm{mg} / \mathrm{kg}$ groups at 42 days of the experiment and in the $48 \mathrm{mg} / \mathrm{kg}$ group at 21 and 42 days compared with corresponding levels in the control group.

The results in Fig. 4g-i shows that the PCNA mRNA and protein expression levels were lower $(p<0.01$ or $p<0.05)$ in the $12 \mathrm{mg} / \mathrm{kg}$ group at 42 days of the experiment and in the 24 and $48 \mathrm{mg} / \mathrm{kg}$ groups at 21 and 42 days than those in the control group.

The mRNA expression levels of p21 were significantly higher $(p<0.01$ or $p<0.05)$ in the $12 \mathrm{mg} / \mathrm{kg}$ groups at 42 days of the experiment and in the 24 and $48 \mathrm{mg} / \mathrm{kg}$ groups at 21 and 42 days than those in the control group, as shown in Fig. 4j. Fig. 4k-l shows that the 21 protein expression levels were significantly increased $(p<0.01$ or $p<0.05)$ in the 12,24 and $48 \mathrm{mg} / \mathrm{kg}$ groups at 21 and 42 days of the experiment compared with corresponding levels in the control group.

The results in Fig. 5a-c shows that the mRNA and protein expression levels of Gadd45a were significantly increased $(p<0.01$ or $p<0.05)$ in the 24 and $48 \mathrm{mg} / \mathrm{kg}$ groups at 21 and 42 days of the experiment in comparison with those in the control group.

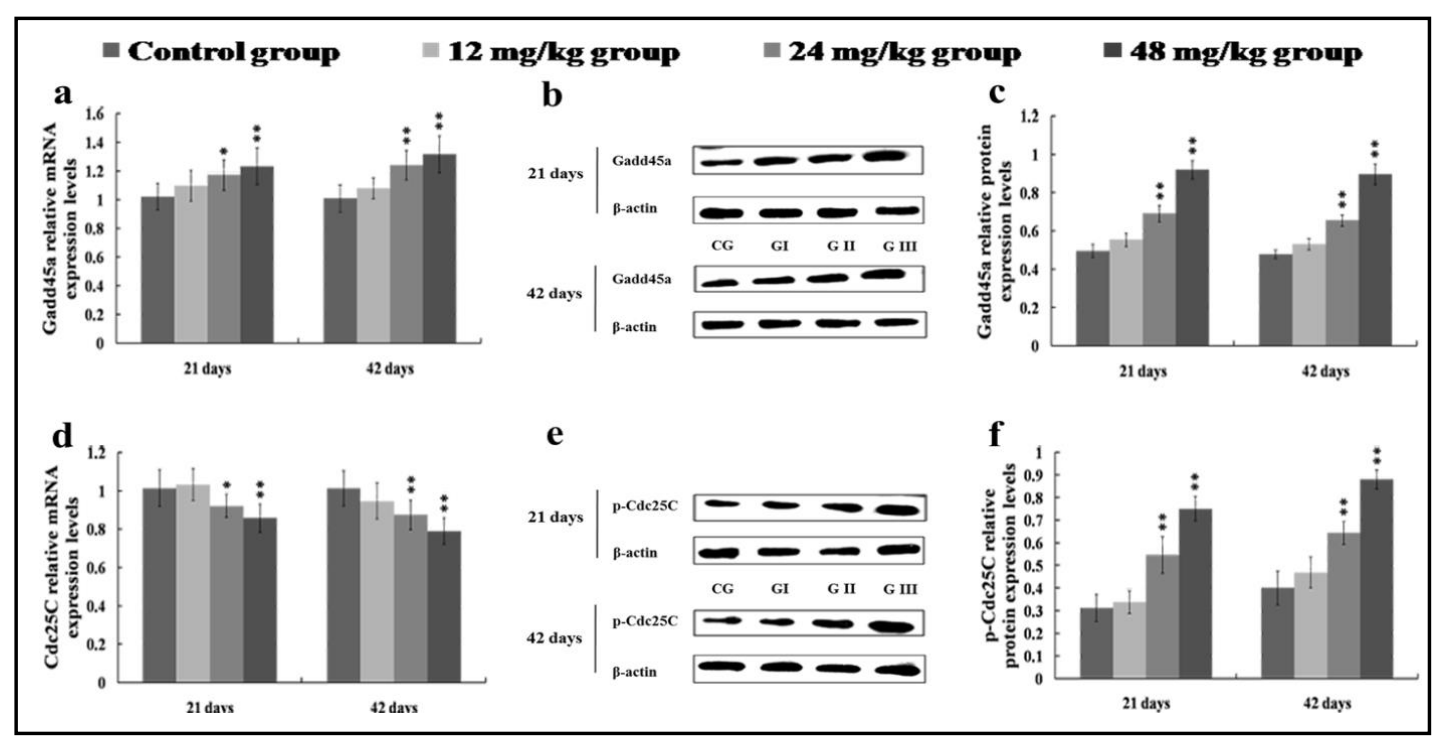

Fig. 5. Changes of mRNA and protein expression levels of Gadd45a, p21 in the kidney at 21 and 42 days of the experiment. a The relative mRNA expression levels of Gadd45a. b The western blot assay of Gadd45a. c The relative protein expression levels of Gadd45a. $d$ The relative mRNA expression levels of Cdc25C. e The western blot assay of p-Cdc25C. f The relative protein expression levels of p-Cdc25C. CG: Control group; GI: $12 \mathrm{mg} / \mathrm{kg}$ group; GII: $24 \mathrm{mg} / \mathrm{kg}$ group; GIII: $48 \mathrm{mg} / \mathrm{kg}$ group. Data are presented with the mean \pm standard deviation $(\mathrm{n}=8),{ }^{*} \mathrm{p}<0.05$, compared with the control group; ${ }^{* *} \mathrm{p}<0.01$, compared with the control group. 


\section{Cellular Physiology Cell Physiol Biochem 2018;51:2421-2433

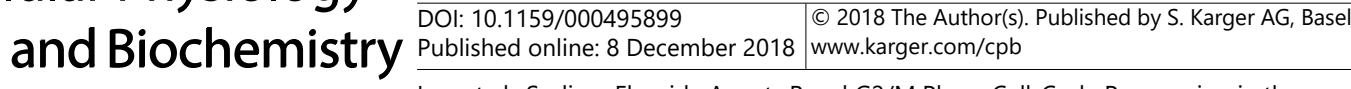 \\ Luo et al.: Sodium Fluoride Arrests Renal G2/M Phase Cell-Cycle Progression in the \\ Mouse}

As shown in Fig. 5d, the Cdc25C mRNA expression levels were lower $(p<0.01$ or $p<$ 0.05 ) in the 24 and $48 \mathrm{mg} / \mathrm{kg}$ groups at 21 and 42 days of the experiment than in the control group. Fig. $5 \mathrm{e}-\mathrm{f}$ shows that $\mathrm{p}-\mathrm{Cdc} 25 \mathrm{C}$ protein expression levels were significantly increased $(p<0.01)$ in the 24 and $48 \mathrm{mg} / \mathrm{kg}$ group at 21 and 42 days of the experiment compared with corresponding levels in the control group.

\section{Discussion}

To explore how NaF induces renal cell-cycle changes, we first used a mouse model to investigate the effects of $\mathrm{NaF}$ on the renal cell-cycle by flow cytometry. The percentages of G2/M phase cells were significantly increased in the 24 and $48 \mathrm{mg} / \mathrm{kg}$ groups compared with percentages in the control group, demonstrating that NaF exposure caused G2/M phase cell-cycle arrest in renal cells of mice. Jothiramajayam et al. [42] have demonstrated that $\mathrm{NaF}$ at low concentrations $(<1 \mu \mathrm{g} / \mathrm{ml})$ induced G0/G1 phase cell-cycle arrest and apoptotic cell death in human lymphocytes. However, Wang et al. [43] reported that NaF can suppress proliferation, S phase cell-cycle arrest and apoptosis in primary mouse osteoblasts. Our results are like those of the report that $\mathrm{NaF}$ can induce G2/M phase cell-cycle arrest and apoptosis in primary cultured rat chondrocytes [44].

Cell-cycle checkpoints are necessary for correct cell-cycle progression [34]. The checkpoint involved in the G2/M phase is controlled by the Cyclin B1/CDK1 complex. The complex is kept inactive through reduction of Cyclin B1 and/or the phosphorylation of CDK1 (Tyr-15) [45]. An inactive Cyclin B1/CDK1 complex does not allow cells to progress beyond the G2/M cell-cycle checkpoint [46]. In this study, the Cyclin B1 and CDK1 mRNA expression levels as well as the Cyclin B1 protein expression levels were lower in the 24 and $48 \mathrm{mg} / \mathrm{kg}$ groups than in the control group, and the p-CDK1 (Tyr-15) protein expression levels were markedly increased in the 24 and $48 \mathrm{mg} / \mathrm{kg}$ groups compared with levels in the control group, suggesting that the activity of Cyclin B1/CDK1 complex was inhibited by NaF and the renal cells were consequently arrested at the G2/M phase.

Recent studies have demonstrated that the activity of Cyclin B1/CDK1 complex is regulated by numerous mechanisms to ensure the proper transition of G2/M phase [47]. Guo et al. [48] have shown that dietary $\mathrm{NiCl}_{2}$ can cause $\mathrm{G} 2 / \mathrm{M}$ phase cell-cycle arrest in kidneys of broiler via ATM-Chk1/Chk2 pathways. Zhang et al. [49] have reported that genistein can induce G2/M cell-cycle arrest via the ATM/p53-dependent pathway in human colon cancer cells. It has been found also that mangiferin can induce cell-cycle arrest at the G2/M phase through the ATR-Chk1 pathway in HL-60 leukemia cells [50]. However, no reported studies have focused on the underlying molecular mechanisms of fluoride-induced G2/M phase cellcycle arrest in vivo and in vitro.

It has been reported that fluoride can induce DNA damage in the kidney [28, 29]. DNA damage generally results in the activation of the ATM-dependent signaling pathway [40]. To explore the molecular mechanism of fluoride-induced G2/M phase cell-cycle arrest, we next examined the effects of $\mathrm{NaF}$ on the key signaling molecules of ATM-dependent signaling pathways. We found that ATM mRNA expression levels and p-ATM (Ser-1981) protein expression levels were increased in the 12,24 and $48 \mathrm{mg} / \mathrm{kg}$ groups, indicating that $\mathrm{NaF}$ induced the activation of ATM. Activated ATM can be recruited at the sites of DNA damage, where it initiates a series of signaling cascades through the phosphorylation of DNA damage-response cell-cycle proteins, including Chk2 and p53 [51]. The Chk2 and p53 mRNA expression levels as well as the p-Chk2 (Thr-68) and p-p53 (Ser-15) protein expression levels were significantly increased in the 12,24 and $48 \mathrm{mg} / \mathrm{kg}$ groups, suggesting that Chk2 was activated by ATM, and p53 then was activated by Chk2. Ha et al. [52] have demonstrated that fluoride can increase the protein expression of p53 in human embryo hepatocytes. Generally, mdm 2 binds to $\mathrm{p} 53$ and suppresses $\mathrm{p} 53$ transcriptional activity, which contributes to the proteolytic degradation of p53 [40]. In the present study, mdm2 mRNA and protein expression levels were decreased in the 24 and $48 \mathrm{mg} / \mathrm{kg}$ groups, demonstrating that $\mathrm{NaF}$ 


\section{Cellular Physiology Cell Physiol Biochem 2018;51:2421-2433

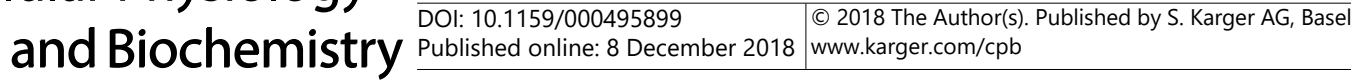 \\ Luo et al.: Sodium Fluoride Arrests Renal G2/M Phase Cell-Cycle Progression in the Mouse}

induced mdm 2 reduction and that this response also contributed to the activation and accumulation of p53. Activated p53 stimulates the transcription of p53-effector genes, such as p21 and Gadd45a. p21, as a CDK inhibitor (CKI), binds to CDK, and regulates CDK activity [53]. Accumulation of p21 can result in CDK1 inhibition and G2/M phase cell-cycle arrest [34]. The regulation of Gadd45a on G2/M phase may be due to its ability to dissociate the complexes of Cyclin B1/CDK1 [54]. Over-expression of Gadd45a can arrest cells at the G2/M phase by inhibiting the activities of Cyclin B1/CDK1 complexes. In this study, we found that the mRNA and protein expression levels of p21 and Gadd45a were significantly increased in the 24 and $48 \mathrm{mg} / \mathrm{kg}$ groups. These results are like those of reports that various stimuli can cause cell-cycle arrest via the activation of p53 and p21 $[55,56]$. The above-mentioned results suggest that the ATM-Chk2-p53 signaling pathway was activated by NaF.

In addition to p53, activated Chk2 can inhibit CDK1 activity by phosphorylating Cdc25C [57]. As a CDK-activating kinase (CAK), Cdc25C is kept in the cytoplasm. Dephosphorylation of CDK1 at tyr-15 induced by Cdc25C is necessary for the activation of CDK1 [58]. In the present study, the Cdc25C mRNA expression levels were reduced, and the p-Cdc25C (Ser216) protein levels were significantly increased in the 24 and $48 \mathrm{mg} / \mathrm{kg}$ groups, indicating that the activation of Cdc25C was inhibited, and the activities of Cyclin B1/CDK1 complexes were then inhibited. These results suggest also that the ATM-Chk2-Cdc25C signaling pathway was activated by NaF. Our findings are like that of the report that UCN-01 can induce G2/M phase cell-cycle arrest through the Chk2/Cdc25C signaling pathway [59].

Prolonged cell-cycle arrest can result in growth arrest or death of cells. Previous studies have demonstrated that p21 can inhibit cellular DNA synthesis by binding to and inhibiting PCNA [60]. PCNA is an essential processivity factor for DNA polymerases, and it also is an index of cell proliferation [61]. Viscera index is usually used to assess the toxic effects of medicines and the development of living tissue $[19,62]$. In this study, the mRNA and protein expression levels of PCNA and the renal viscera index were reduced in the 24 and $48 \mathrm{mg} / \mathrm{kg}$ groups, suggesting that the proliferation of renal cells and development of the kidney were suppressed. These suppressive effects may be due to the renal G2/M phase cell-cycle arrest induced by $\mathrm{NaF}$.

\section{Conclusion}

In a mouse model, $\mathrm{NaF}$, at more than $12 \mathrm{mg} / \mathrm{kg}$, induced renal G2/M phase cell-cycle arrest by increasing the protein expression levels of p-ATM, p-Chk2, p-p53, p-Cdc25C, p-CDK1, p21, and Gadd45a; increasing the mRNA expression levels of ATM, Chk2, p53, p21, and Gadd45a; reducing the protein expression levels of CyclinB $_{1}, \mathrm{mdm} 2, \mathrm{PCNA}$; and reducing mRNA expression levels of $\mathrm{Cyclin}_{1}, \mathrm{CDK} 1, \mathrm{Cdc} 25 \mathrm{C}, \mathrm{mdm} 2$, and PCNA. These results ultimately inhibited the proliferation of renal cells and the development of the kidney, as determined by the viscera index. Activation of the ATM-Chk2-p53/Cdc25C signaling pathway is the mechanism of NaF-induced renal G2/M phase cell-cycle arrest in the mouse model. Relevance of these findings to fluoride toxicity in humans should be studied in the future.

\section{Acknowledgements}

This research was supported by the program for Changjiang scholars and the university innovative research team (IRT 0848), and the Shuangzhi project of Sichuan Agricultural University (03571800; 03572437).

\section{Disclosure Statement}

The authors declare that there are no conflicts of interest.

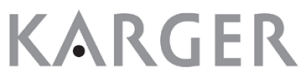




\section{Cellular Physiology Cell Physiol Biochem 2018;51:2421-2433

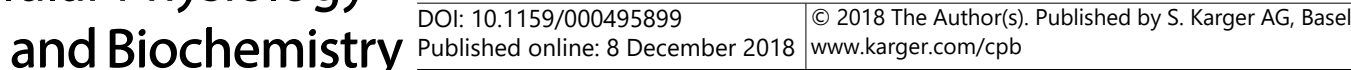 \\ Luo et al.: Sodium Fluoride Arrests Renal G2/M Phase Cell-Cycle Progression in the Mouse}

\section{References}

1 Mandinic Z, Curcic M, Antonijevic B, Carevic M, Mandic J, Djukic-Cosic D, Lekic CP: Fluoride in drinking water and dental fluorosis. Sci Total Environ 2010;408:3507-3512.

2 Švarc-Gajić J, Stojanović Z, Vasiljević I, Kecojević I: Determination of fluorides in pharmaceutical products for oral hygiene. J Food Drug Anal 2013;21:384-389.

- 3 Ameeramja J, Panneerselvam L, Govindarajan V, Jeyachandran S, Baskaralingam V, Perumal E: Tamarind seed coat ameliorates fluoride induced cytotoxicity, oxidative stress, mitochondrial dysfunction and apoptosis in A549 cells. J Hazard Mater 2015;301:554-565.

4 WHO, Guidelines for Drinking Water Quality, 45, World Health Organization, Geneva, 1993.

5 Chen N, Zhang ZY, Feng CP, Li M, Zhu DR, Chen RZ, Sugiura N: An excellent fluoride sorption behavior of ceramic adsorbent. J Hazard Mater 2010;183:460-465.

-6 Death C, Coulson G, Kierdorf U, Kierdorf H, Morris WK, Hufschmid J: Dental fluorosis and skeletal fluoride content as biomarkers of excess fluoride exposure in marsupials. Sci Total Environ 2015;533:528-541.

-7 Irigoyencamacho ME, García PA, Mejía GA, Huizar AR: Nutritional status and dental fluorosis among school children in communities with different drinking water fluoride concentrations in a central region in mexico. Sci Total Environ 2015;541:512-519.

8 Zhang KL, Lou DD, Guan ZZ: Activation of the AGE/RAGE system in the brains of rats and in SH-SY5Y cells exposed to high level of fluoride might connect to oxidative stress. Neurotoxicol Teratol 2015;48:49-55.

-9 Zheng X, Sun Y, Ke L, Ouyang W, Zhang Z: Molecular mechanism of brain impairment caused by drinkingacquired fluorosis and selenium intervention. Environ Toxicol Phar 2016;43:134-139.

10 Mukhopadhyay D, Priya P, Chattopadhyay A: Sodium fluoride affects zebrafish behaviour and alters mRNA expressions of biomarker genes in the brain: Role of Nrf2/Keap1. Environ Toxicol Phar 2015;40:352-359.

11 Stawiarska-Pięta B, Grzegorzak N, Kuczera K, Helis A, Zalejska-Fiolka J, Bielec B, Birkner E, Kubina R: The effect of antioxidants on the morphological picture of thymus and heart of rats intoxicated with sodium fluoride. Toxicol Lett 2013;221:S77.

12 Chen T, Cui HM, Cui Y, Bai CM, Gong T, Peng X: Cell-cycle blockage associated with increased apoptotic cells in the thymus of chickens fed on diets high in fluorine. Hum Exp Toxicol 2011;30:685-692.

$\checkmark 13$ Zhao LN, Yu YN, Deng CN: Protein and mRNA expression of Shh, Smo and Gli1 and inhibition by cyclopamine in hepatocytes of rats with chronic fluorosis. Toxicol Lett 2014;225:318-324.

14 Mukhopadhyay D, Chattopadhyay A: Induction of oxidative stress and related transcriptional effects of sodium fluoride in female zebrafish liver. B Environ Contam Tox 2014;93:64-70.

15 Mukhopadhyay D, Srivastava R, Chattopadhyay A: Sodium fluoride generates ROS and alters transcription of genes for xenobiotic metabolizing enzymes in adult zebrafish (Danio rerio) liver: expression pattern of Nrf2/Keap1 (INrf2). Toxicol Mech Method 2015;25:1-10.

16 Oyagbemi AA, Omobowale TO, Asenuga ER, Adejumobi AO, Ajibade TO, Ige TM, Ogunpolu BS, Adedapo AA, Yakubu MA: Sodium fluoride induces hypertension and cardiac complications through generation of reactive oxygen species and activation of nuclear factor kappa beta. Environ Toxicol 2016;32:1089-1101.

-17 Shanmugam T, Selvaraj M, Poomalai S: Epigallocatechin gallate potentially abrogates fluoride induced lung oxidative stress, inflammation via Nrf2/Keap1 signaling pathway in rats: An in-vivo and in-silico study. Int Immunopharmacol 2016;39:128-139.

18 Kuang P, Deng HD, Cui HM, Chen L, Guo HR, Fang J, Zuo ZC, Deng JL, Wang X, Zhao L: Suppressive effects of sodium fluoride on cultured splenic lymphocyte proliferation in mice. Oncotarget 2016;7:61905-61915.

19 Kuang P, Deng HD, Cui HM, Chen L, Fang J, Zuo ZC, Deng JL, Wang X, Zhao L: Sodium fluoride (NaF) causes toxic effects on splenic development in mice. Oncotarget 2017;8:4703-4717.

20 Deng HD, Kuang P, Cui HM, Chen L, Fang J, Zuo ZC, Deng JL, Wang X, Zhao L: Sodium fluoride induces apoptosis in cultured splenic lymphocytes from mice. Oncotarget 2016;7:67880-67900.

21 Deng HD, Kuang P, Cui HM, Chen L, Luo Q, Fang J, Zuo ZC, Deng JL, Wang X, Zhao L: Sodium fluoride (NaF) induces the splenic apoptosis via endoplasmic reticulum (ER) stress pathway in vivo and in vitro. Aging-US 2016;8:3552-3567.

22 Chauhan SS, Ojha S, Mahmood A: Modulation of lipid peroxidation and antioxidant defense systems in rat intestine by subchronic fluoride and ethanol administration. Alcohol 2011;45:663-672.

23 Luo Q, Cui HM, Peng X, Fang J, Zuo ZC, Deng JL, Liu J, Deng YB: Suppressive effects of dietary high fluorine on the intestinal development in broilers. Biol Trace Elem Res 2013;156:153-165. 


\section{Cellular Physiology Cell Physiol Biochem 2018;51:2421-2433 and Biochemistry \begin{tabular}{l|l} 
DOI: 10.1159/000495899 2018 The Author(s). Published by S. Karger AG, Basel \\
(c)
\end{tabular}

Luo et al.: Sodium Fluoride Arrests Renal G2/M Phase Cell-Cycle Progression in the

Mouse

24 Liu J, Cui HM, Peng X, Fang J, Zuo ZC, Wang HS, Wu BY, Deng YX, Wang KP: Dietary high fluorine induces apoptosis and alters Bcl-2, Bax, and Caspase-3 protein expression in the cecal tonsil lymphocytes of broilers. Biol Trace Elem Res 2013;152:25-30.

25 Liu J, Cui HM, Peng X, Fang J, Zuo ZC, Deng JL, Wang HS, Wu BY, Deng YX, Wang KP: Decreased IgA+ B cells population and IgA, IgG, IgM contents of the cecal tonsil induced by dietary high fluorine in broilers. Inter J Env Res Pub Heal 2013;10:1775-1785.

26 Wei R, Luo G, Sun Z, Wang S, Wang J: Chronic fluoride exposure-induced testicular toxicity is associated with inflammatory response in mice. Chemosphere 2016;153:419-425.

27 Chen T, Cui HM, Cui Y, Bai CM, Gong T: Effect of dietary high fluorine on the morphologic structure, cell cycle and apoptosis of bursa of fabricius in broilers. Chinese J Anim Vet Sci 2009;40:1235-1243.

-28 Song GH, Gao JP, Wang CF, Chen CY, Yan XY, Guo M, Wang Y, Huang FB: Sodium fluoride induces apoptosis in the kidney of rats through caspase-mediated pathways and DNA damage. J Physiol Biochem 2014;70:857868.

29 Cao J, Chen J, Xie L, Wang J, Feng C, Song J: Protective properties of sesamin against fluoride-induced oxidative stress and apoptosis in kidney of carp (Cyprinus carpio) via JNK signaling pathway. Aquat Toxicol 2015;167:180-190.

30 Luo Q Cui HM, Deng HD, Kuang P, Liu H, Lu YJ, Fang J, Zuo ZC, Deng JL, Li YL, Wang X, Zhao L: Histopathological findings of renal tissue induced by oxidative stress due to different concentrations of fluoride. Oncotarget. 2017;8:50430-50446.

-31 Shirazi FS, Allericsson C, Hallböök F: The heterogenic final cell cycle of chicken retinal Lim1 horizontal cells is not regulated by the DNA damage response pathway. Cell Cycle 2014;13:408-417.

32 Peco E, Escude T, Agius E, Sabado V, Medevielle F, Ducommun B, Pituello F: The CDC25B phosphatase shortens the G2 phase of neural progenitors and promotes efficient neuron production. Development 2012;139:1095-1104.

-33 Giglio S, Cirombella R, Amodeo R, Portaro L, Lavra L,Vecchione A: MicroRNA miR-24 promotes cell proliferation by targeting the CDKs inhibitors p27Kip1 and p16INK4a. J Cell Physiol 2013;228:2015-2023.

34 Vermeulen K, Van Bockstaele DR, Berneman ZN: The cell cycle: a review of regulation, deregulation and therapeutic targets in cancer. Cell Proliferat 2003;36:131-149.

35 Sturgeon CM1, Knight ZA, Shokat KM, Roberge M: Effect of combined DNA repair inhibition and G2 checkpoint inhibition on cell cycle progression after DNA damage. Mol Cancer Ther 2006;5:885-892.

36 Li T, Ning K, Jiang L, Tan M, Ludwig T, Zhao YM, Baer R, Gu W: Tumor suppression in the absence of p53mediated cell-cycle arrest, apoptosis, and senescence. Cell 2012;149:1269-1283.

37 Bai CM, Chen T, Cui Y, Gong T, Peng X, Cui HM: Effect of high fluorine on the cell cycle and apoptosis of renal cells in chickens. Biol Trace Elem Res 2010;138:173-180.

-38 Yu RA, Xia T, Wang AG: Effects of selenium and zinc on renal oxidative stress and apoptosis induced by fluoride in rats. Biomed Environ Sci 2006;19:439-444.

39 Chen B, Zhong Y, Zhong WK, Zou ZH, Chen ZT, Wei XL, Deng RS, Lin QY, Dong CY, Yu RA: Time-effect and dose-effect of fluoride on cell cycle arrest in rat liver and kidney cells. J Environ Health 2013;30:317-320.

-40 Yang J, Xu ZP, Huang Y, Hamrick HE, Duerksen-Hughes PJ, Yu YN: ATM and ATR: sensing DNA damage. World J Gastroentero 2004;10:155-160.

-41 Livak KJ, Schmittgen TD: Analysis of relative gene expression data using real-time quantitative PCR and the $2^{-\Delta \Delta C T}$ method. Methods 2001;25:402-408.

$>42$ Jothiramajayam M, Sinha S, Ghosh M, Nag A, Jana A, Mukherjee A: Sodium fluoride promotes apoptosis by generation of reactive oxygen species in human lymphocytes. J Toxicol Env Heal A 2014;77:1269-1280.

43 Wang Z, Yang X, Yang S, Ren G, Ferreri M, Su Y, Chen L, Han B: Sodium fluoride suppress proliferation and induce apoptosis through decreased insulin-like growth factor-I expression and oxidative stress in primary cultured mouse osteoblasts. Arch Toxicol 2011;85:1407-1417.

44 Meng H, Zhang T, Liu W, Wang H, Wang C, Zhao Z, Liu N, Wang W: Sodium fluoride induces apoptosis through the downregulation of hypoxia-inducible factor- $1 \alpha$ in primary cultured rat chondrocytes. Int J Mol Med 2014;33:351-358.

45 Porter LA, Donoghue DJ: Cyclin B1 and CDK1: nuclear localization and upstream regulators. Prog Cell Cycle Res 2003;5:335-347. 


\section{Cellular Physiology Cell Physiol Biochem 2018;51:2421-2433 \begin{tabular}{ll|l} 
and Biochemistry Published online: 8 December 2018 & $\begin{array}{l}\text { @ } 2018 \text { The Author(s). Published by S. Karger AG, Basel } \\
\text { www.karger.com/cpb }\end{array}$ \\
\hline
\end{tabular}}

Luo et al.: Sodium Fluoride Arrests Renal G2/M Phase Cell-Cycle Progression in the Mouse

-46 Wang ZQ, Fan M, Candas D, Zhang TQ, Qin LL, Eldridge A, Wachsmann-Hogiu S, Ahmed KM, Chromy BA, Nantajit D, Duru N, He FC, Chen M, Finkel T, Weinstein LS, Li JJ: CyclinB1/Cdk1 Coordinates mitochondrial respiration for cell cycle G2/M progression. Dev Cell 2014;29:217-232.

47 Qian W, Choi S, Gibson GA, Watkins SC, Bakkenist CJ, Van Houten B: Mitochondrial hyperfusion induced by loss of the fission protein Drp1 causes ATM-dependent G2/M arrest and aneuploidy through DNA replication stress. J Cell Sci 2012;125:5745-5757.

48 Guo HR, Deng HD, Cui HM, Peng X, Fang J, Zuo ZC, Deng JL, Wang X, Wu BY, Chen KJ, Deng J: Dietary NiCl2 causes G2/M cell cycle arrest in the broiler's kidney. Oncotarget 2015;6:35964-35977.

-49 Zhang Z, Wang CZ, Du GJ, Qi LW, Calway T, He TC, Du W, Yuan CS: Genistein induces G2/M cell cycle arrest and apoptosis via ATM/p53-dependent pathway in human colon cancer cells. Int J Oncol 2013;43:289-296.

50 Peng ZG, Yao YB, Yang J, Tang YL, Huang X: Mangiferin induces cell cycle arrest at G2/M phase through ATRChk1 pathway in HL-60 leukemia cells. Genet Mol Res 2015;14:4989-5002.

-51 Sahu RP, Batra S, Srivastava SK: Activation of ATM/Chk1 by curcumin causes cell cycle arrest and apoptosis in human pancreatic cancer cells. Brit J Cancer 2009;100:1425-1433.

52 Ha J, Chu Q Wang A, Xia T, Yang K: Effects on DNA damage and apoptosis and p53 protein expression induced by fluoride in human embryo hepatocytes. J Hyg Res 2004;33:400-402.

53 Wang Y, Fisher JC, Mathew R, Ou L, Otieno S, Sublet J, Xiao L, Chen J, Roussel MF, Kriwacki RW: Intrinsic disorder mediates the diverse regulatory functions of the Cdk inhibitor p21. Nat Chem Biol 2011;7:214221.

54 Hildesheim J, Bulavin DV, Anver MR, Alvord WG, Hollander MC, Vardanian L, Fornace AJ Jr: Gadd45a protects against UV irradiation-induced skin tumors, and promotes apoptosis and stress signaling via MAPK and p53. Cancer Res 2002;62:7305-7315.

55 Wright JW, Stouffer RL, Rodland KD: High-dose estrogen and clinical selective estrogen receptor modulators induce growth arrest, p21, and p53 in primate ovarian surface epithelial cells. J Clin Endocr Metab 2005;90:3688-3695.

-56 Igata M, Motoshima H, Tsuruzoe K, Kojima K, Matsumura T, Kondo T, Taguchi T, Nakamaru K, Yano M, Kukidome D: Adenosine monophosphate-activated protein kinase suppresses vascular smooth muscle cell proliferation through the inhibition of cell cycle progression. Circ Res 2005;97:837-844.

57 Bulavin DV, Higashimoto Y, Demidenko ZN, Meek S, Graves P, Phillips C, Zhao H , Moody SA, Appella E, Piwnica-Worms H, Fornace AJ Jr: Dual phosphorylation controls Cdc25 phosphatases and mitotic entry. Nat Cell Biol 2003;5:545-551.

58 Timofeev O, Cizmecioglu O, Settele F, Kempf T, Hoffmann I: Cdc25 phosphatases are required for timely assembly of CDK1-cyclin B at the G2/M transition. J Biol Chem 2010;285:16978-16990.

59 Wu GY, Xu LN, Lin N, Liu B: UCN-01 induces S and G2/M cell cycle arrest through the p53/p21 waf1 or CHK2/CDC25C pathways and can suppress invasion in human hepatoma cell lines. BMC cancer 2014;14:167-175.

60 Soria G, Speroni J, Podhajcer OL, Prives C, Gottifredi V: p21 differentially regulates DNA replication and DNA-repair-associated processes after UV irradiation. J Cell Sci 2008;121:3271-3282.

61 Papouli E, Chen S, Davies AA, Huttner D, Krejci L, Sung P, Ulrich HD: Crosstalk between SUMO and ubiquitin on PCNA is mediated by recruitment of the helicase Srs2p. Mol Cell 2005;19:123-133.

62 Yuan BL: The significance and shortcoming of organ/body weight ratio used in drug safety evaluation. Chinese New Drugs J 2003;12:960-963. 